\title{
Effects of harvesting and density dependence on the demography of sandy beach populations: the yellow clam Mesodesma mactroides of Uruguay
}

\author{
Alejandro Brazeiro ${ }^{1, *}$, Omar Defeo ${ }^{2,3}$ \\ ${ }^{1}$ Departamento de Ecología, Facultad de Ciencias Biológicas, P. Universidad Católica de Chile, \\ Casilla 114-D, Santiago, Chile \\ ${ }^{2}$ Instituto Nacional de Pesca, Constituyente 1497, 11200 Montevideo, Uruguay \\ ${ }^{3}$ CINVESTAV-IPN Unidad Mérida, AP 73 Cordemex, 97310 Mérida, Yucatán, Mexico
}

\begin{abstract}
Sandy beach ecologists concur that natural populations living in these harsh environments are controlled almost exclusively by physical factors, biotic factors being largely irrelevant. This paper provides evidence that human-induced perturbations as well as biotic, density-dependent processes also influence sandy beach populations. Results were obtained from a long-term study ( 8 yr) of the artisanally harvested yellow clam Mesodesma mactroides on a Uruguayan exposed sandy beach. The study included an experimental manipulation of fishing effort based on the closure of the clam fishery for 32 consecutive months. Fine-scale demographic parameters, such as age-specific survival probability and fertility, as well as coarse-scale demographic parameters, such as age composition, elasticity to demographic parameters, adult clam density, and population growth rate, were significantly affected by fishing effort and/or adult density. These results yield useful information from the management and conservation points of view, such as the threshold range of parent stock densities and fishing mortality levels capable of supporting a sustainable yield over time. Critical demographic parameters for population growth rate are also highlighted.
\end{abstract}

KEY WORDS: Demography · Density dependence - Harvesting · Sandy beach - Fishery - Management . Human impact · Matrix model · Elasticity · Long-term

\section{INTRODUCTION}

Most sandy beach ecologists consider as a paradigm exposed sandy beaches to constitute physically stressed environments (sensu McLachlan 1983, 1988) where invertebrate populations and communities are controlled by physical factors. Thus, it is thought (McLachlan 1988, 1990) that the best way to understand population variability in these ecosystems is by documenting responses to abiotic factors (e.g. Jaramillo \& McLachlan 1993, McLachlan et al. 1993. 1996, Borzone et al. 1996). However, there is a con-

•E-mail: eabrazei@genes.bio.puc.cl spicuous lack of information on biotic factors (e.g. larvae-adult interactions, density dependence) as well as on human-induced impacts (e.g. fishing) (but see Defeo \& de Alava 1995, Defeo 1996a,b, 1998).

From a management point of view, it is crucial to determine the role of density dependence in the dynamics of exploited populations. This is particularly relevant in intertidal shellfishes, variations in the harvesting intensity of which could produce drastic changes in their abundance, population dynamics and strength of intraspecific interactions, as demonstrated for rocky shores (Castilla \& Durán 1985, Oliva \& Castilla 1986; see review in Castilla 1993). It is also important to determine how harvesting operates at a fine demographic resolution (e.g. age-specific survival 
and fertility), and to evaluate the contribution of each demographic parameter in the determination of the population growth rate under different harvesting intensity levels.

The yellow clam Mesodesma mactroides (Bivalvia: Mesodesmatidae) inhabits $22 \mathrm{~km}$ of uninterrupted sandy beach from Barra del Chuy to La Coronilla, Uruguay. It is artisanally harvested by fishermen with shovels, and occupies second place among molluscan resources exploited on the Atlantic coast of Uruguay (Defeo 1989). Yellow clam catches varied from $62 \mathrm{t}$ in 1981 to a peak of $219 \mathrm{t}$ in 1985, after which catch and catch per unit effort (CPUE) decreased rapidly (Defeo 1989). The fishery was closed for $32 \mathrm{mo}$ (April 1987 to November 1989) along the $22 \mathrm{~km}$ sandy beach, with the collaboration of the fishermen and the coastal marine authority. This closure may be interpreted as a human exclusion experiment, in order to assess the role of human predation on the yellow clam demography (see also Defeo 1996a, 1998).

In this paper we report an 8 yr study of the yellow clam Mesodesma mactroides population at Barra del Chuy beach. We separately evaluate the role of harvesting and density dependence on demographic processes (survival and fertility) and population structure (age composition) and dynamics (population density), as well as the relative importance of each demographic parameter in determining the population growth rate. To this end, we estimated annual densities of population components (i.e. adults and recruits) as well as age-specific survival probability and fertility. The estimated annual vital rates were used as input parameters to build age-specific matrix models for each year. Each matrix model was projected to estimate the population growth rate, the stable age structure, and the elasticity of the population growth rate to the different vital rates (see Caswell 1989).

\section{METHODS}

Study area. The study was carried out at Barra del Chuy beach, on the eastern coast of Uruguay $\left(33^{\circ} 40^{\prime} \mathrm{S}\right.$, $53^{\circ} 29^{\prime} \mathrm{W}$ ). It is a sandy coastal belt $22 \mathrm{~km}$ in length, enclosed by the Chuy stream on the north and the Andreoni Canal on the south. This dissipative beach (sensu Short \& Wright 1983), of gentle slope (4\%) and fine sand (2.22 ф) (Defeo 1985, 1993, Brazeiro 1993) has the highest values of species richness (17 species), diversity, density and biomass among Uruguayan sandy beaches (Defeo et al. 1992a).

The yellow clam Mesodesma mactroides. Mesodesma mactroides is a fast-growing, short-lived pelecypod. Its age structure, determined by the interpreta- tion of growth rings externally recorded and by shell sectioning techniques, indicates an average maximum life span of ca 4 yr (Defeo et al. 1992b). M. mactroides has a high fecundity, producing about 5.3 million ( $\mathrm{SD}=$ 2.8 million) eggs female ${ }^{-1}$. A free-floating larva with a variable pelagic stage ( 2 to $3 \mathrm{wk}$ ) reverses its phototactic response and settles in the intertidal zone from January to May, peaking in March and April $187 \%$ of the total) (Defeo et al. 1992b). The mean shell length at sexual maturity is nearly $43 \mathrm{~mm}$ (ca 1 yr old: Masello \& Defeo 1986). Thus, sexually ripe individuals belonging to Age classes 1 to 3 are responsible for recruitment (Masello \& Defeo 1986). The sex ratio is 1:1 (Defeo 1985).

Sampling design. Samples of Mesodesma mactroides were obtained monthly from March 1983 through March 1985, and seasonally (at least 4 times a year) from 1985 to 1990, according to a systematic design. Transects perpendicular to the shoreline were set up every kilometer from Barra del Chuy stream to Andreoni Canal. Samples were obtained every $4 \mathrm{~m}$, from the base of the sand dunes to the shore level, where 2 successive samples without clams were recorded. The samples were obtained with a corer $28.2 \mathrm{~cm}$ in diameter and $40 \mathrm{~cm}$ in depth; some $200 \mathrm{sam}$ ples were analyzed during each sampling period. The sediment of each sample was sieved separately through a $0.5 \mathrm{~mm}$ mesh, and all clams retained were measured (maximum valve length) and counted. In general, the full range of sizes (1 to $76 \mathrm{~mm}$ ) was recorded for all sample periods, more than 100000 individuals being measured throughout the study. Records of fishing effort (number of trips) from 1982 to 1990 were obtained with the collaboration of fishermen and the coastal marine authority (see Defeo 1998 for details).

Estimation of demographic parameters. Given that recruitment is discrete in time with a main peak within the year, the Mesodesma mactroides population can be modeled as a 'birth-pulse population' by means of a post-breeding census (sensu Caswell 1989). Thus, only those samples after the recruitment peak of each year were considered to estimate the demographic parameters.

Survival probability $\left(\boldsymbol{S}_{i}\right)$ : Individuals collected during each year were separated into 5 age classes ( 0 to 4 ), according to an age-size key derived from the seasonal version of the von Bertalanffy growth model reported by Defeo et al. (1992b). The age-size key is as follows: Age class 0 clams, from 1 to $38 \mathrm{~mm}_{i}$ Age class 1, 39 to $56 \mathrm{~mm}$; Age class 2, 57 to $66 \mathrm{~mm}$; Age class 3, 67 to $73 \mathrm{~mm}$; and Age class 4,74 to $76 \mathrm{~mm}$.

Annual estimates of age structure were made on the basis of models fitted to each annual age distribution. We used the estimated age distribution rather than the 
observed, because in some cases the measured abundance of Age class 4 was higher than the abundance of Age class 3, probably due to sampling bias, generating therefore nonsensical survival estimates (i.e. $S_{i}>1$ ). This is a common procedure in demographic studies (see Eberhardt 1988). The annual age distributions were adequately described by an exponential model in the form:

$$
\log \left(N_{1}\right)=a \cdot e^{-b \cdot i}
$$

where $N_{1}$ denotes the abundance of age $i$, and $a$ and $b$ are model parameters. The results of fitting Eq. (1) to the age distribution of each of the $8 \mathrm{yr}$ analyzed (see Table 1) were used to estimate the relative abundance of each age class $\left(l_{i}\right)$. The age-specific survival probabilities $\left(S_{i}\right)$ were estimated as follows:

$$
S_{i}=\frac{l_{i+1}}{l_{i}}
$$

Because the yellow clam population was not in equilibrium (i.e. population growth rate different from 1), $S_{1}$ estimates were corrected by the observed population growth rate $\left(\lambda_{0}\right)$ recorded each year, following Eberhardt (1988). $\lambda_{0}$ values were calculated as the rate of change in population density from time $t$ to $t+1$. No individuals of Age class 4 survive at the end of the projection interval (i.e. $S_{4}=0$ ).

Fertility $\left(F_{i}\right)$ : The fertility of each age class $\left(F_{i}\right)$ is the average number of Age class 0 individuals (i.e. recruits) produced per female of age class $i$. To estimate $F_{i}$ we partitioned the number of recruits observed in each year among the corresponding reproductive females in proportion to their relative index of reproductive output $\left(m_{i}\right)$. The $m_{i}$ values were estimated as the average gonad volume of each age class given by the following relationship: gonad volume $=6.9 \times 10^{-5} \times$ shell length ${ }^{3}$ (Masello unpubl. data). According to Caswell (1989), the actual reproductive output of a given age class must be weighted by its survival prob-

Table 1. Results of the survival model $\left[\log \left(N_{i}\right)=a \cdot e^{-b \cdot 1}\right]$ fitted for each of the 8 years analyzed ( $p<0.05$ in all cases). The estimated parameters ( $a$ and $b$ ), correlation coefficient ( $\mathrm{r}$ ), and the relative age-specific abundance are

\begin{tabular}{|c|c|c|c|c|c|c|c|c|}
\hline \multirow[t]{2}{*}{ Year } & \multicolumn{3}{|c|}{ Parameter } & \multicolumn{5}{|c|}{ Relative abundance per age class } \\
\hline & a & $-b$ & r & 0 & 1 & 2 & 3 & 4 \\
\hline 1983 & 18.94 & 0.73 & -0.99 & 1 & 0.0088 & 0.0009 & 0.0003 & 0.0002 \\
\hline 1984 & 13.49 & 0.36 & -0.94 & 1 & 0.0573 & 0.0073 & 0.0020 & 0.0008 \\
\hline 1985 & 13.44 & 0.36 & -0.94 & 1 & 0.0590 & 0.0082 & 0.0021 & 0.0008 \\
\hline 1986 & 10.93 & 0.31 & -0.85 & 1 & 0.1169 & 0.0241 & 0.0077 & 0.0033 \\
\hline 1987 & 12.43 & 0.46 & -0.94 & 1 & 0.0550 & 0.0089 & 0.0028 & 0.0014 \\
\hline 1988 & 25.74 & 1.41 & -0.99 & 1 & 0.0874 & 0.0029 & 0.0021 & 0.0019 \\
\hline 1989 & 11.07 & 0.62 & -0.93 & 1 & 0.0640 & 0.0145 & 0.0658 & 0.0042 \\
\hline 1990 & 7.33 & 0.61 & -0.95 & 1 & 0.1623 & 0.0604 & 0.0359 & 0.0264 \\
\hline
\end{tabular}
presented ability to calculate its fertility $\left(F_{i}\right)$. Thus, we estimated the age-specific fertility as:

$$
F_{i}=\frac{\frac{R \cdot m_{i} \cdot N_{i}}{\sum_{i=1}^{i=3} m_{i} \cdot N_{i}}}{N_{i}} \cdot S_{i}
$$

where $R$ is the number of recruits and $N$, the number of adult females in Age classes 1, 2 or $3 . F_{4}$ is zero because $S_{4}$ is zero, and $F_{0}$ is also zero because Age class 0 individuals are sexually immature.

The matrix model. In order to calculate the annual estimated population growth rate $\left(\lambda_{e}\right)$, the stable age structure and elasticity of $\lambda_{e}$, the demographic parameters estimated for each year were used as parameters of age-specific matrix model of the form:

$$
n(t+1)=\mathbf{A} \cdot n(t)
$$

where $n(t+1)$ and $n(t)$ are the vectors of age-specific abundance at time $t+1$ and $t$, respectively, and $A$ is the projection matrix (sensu Caswell 1989) of Mesodesma mactroides population, built on an annual interval as follows:

$A=\left[\begin{array}{lllll}0 & F_{1} & F_{2} & F_{3} & \overline{F_{4}} \\ S_{0} & 0 & 0 & 0 & 0 \\ 0 & S_{1} & 0 & 0 & 0 \\ 0 & 0 & S_{2} & 0 & 0 \\ 0 & 0 & 0 & S_{3} & \underline{0}\end{array}\right]$

This model assumes that the yellow clam is a closed population. There is some evidence to support this: (1) It has been stated that dissipative sandy beaches are semiclosed ecosystems, as a consequence of coastal circulation patterns that regularly bring larvae and surf phytoplankton back nearshore (see Efford 1970, McLachlan 1983). (2) Barra del Chuy beach is enclosed between 2 freshwater barriers, the Andreoni Canal and the Barra del Chuy stream, that mitigate larval immigration. (3) Previous long-term studies found a closed relationship between covariations in the exploited stock and harvesting pressure (Defeo 1993, 1998), also suggesting that the yellow clam population of Barra del Chuy could be modeled as a closed system.

The estimated values of $\lambda_{e}$ were $a b$ tained from the dominant eigenvalue of the projection matrix, the age-specific reproductive values were estimated by the left eigenvector, and the age-specific relative abundance when the stable age distribution has been reached was calculated as the right eigenvector (Caswell 1989).

All of the parameters of the projection matrix contribute to determine $\lambda_{e}$, but not 
necessarily in the same way. In this sense, sensitivity and elasticity analyses are useful tools to measure how much $\lambda_{e}$ depends on each parameter. Sensitivity gives the absolute contribution of each parameter when the others are maintained constant, whereas elasticity gives the relative contributions. Elasticity is more useful for comparative purposes. The sensitivity of $\lambda_{e}$ to the vital rates $S_{i}$ and $F_{i}$ was calculated following Caswell (1989), as

$$
\frac{\delta \lambda}{\delta a_{i j}}=\frac{v_{i} \cdot \omega_{j}}{\left\langle v_{1} \omega\right\rangle}
$$

where $a_{i j}$ denotes the element $i j$ of the projection matrix $A_{1} v_{i}$ represents the reproductive value of age $i$, $\omega_{i}$ is the abundance proportion of age $i$ when the stable age structure has been reached, and $\langle v, \omega\rangle$ is the scalar product of the 2 vectors. The elasticity $\left(e_{i j}\right)$ (i.e. standardized sensitivity) was also calculated following Caswell (1989):

$$
e_{i j}=\frac{a_{i j}}{\lambda} \cdot \frac{\delta \lambda}{\lambda a_{i j}}
$$

\section{RESULTS}

\section{Vital rates}

Survival probabilities increased toward older age classes $(r=0.76, p \ll 0.01$, analysis performed with arc$\sin \sqrt{x}$ transformed data), varying from (mean $\pm \mathrm{SD}$ ) $0.08 \pm 0.05$ for Age class 0 to $0.87 \pm 0.27$ for individuals of Age class 3 (Fig. 1). Fertility also increased with age $(r=0.39, p=0.063)$, from $12.6 \pm 10.0$ recruits female f $^{-1}$ in Age class 1 to $31.5 \pm 23.9$ recruits female $^{-1}$ in Age class 3 (Fig. 1).

Fishing effort and population density were not correlated ( $\mathrm{r}=0.49, \mathrm{p}=0.22$ ), and therefore their effects on Mesodesma mactroides vital rates could be evaluated

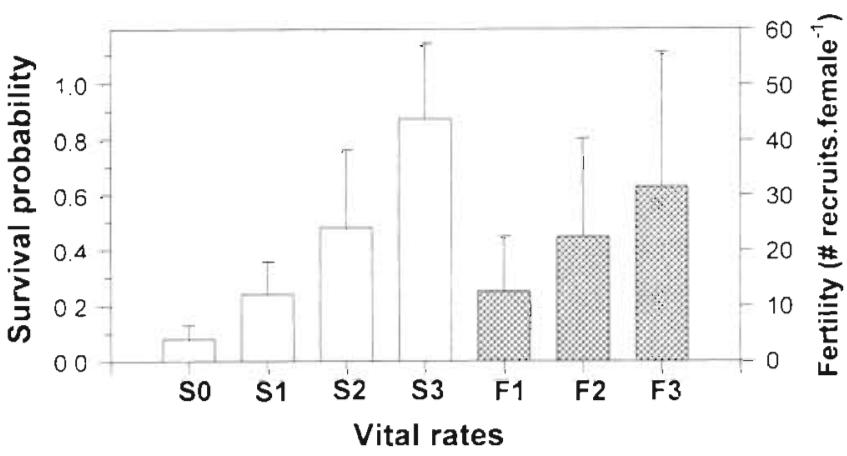

Fig. 1. Mesodesma mactroides. Long-term patterns in agespecific survival probability $\left(S_{1}\right)$ and fertility $\left(F_{l}\right)$ (mean \pm SD)

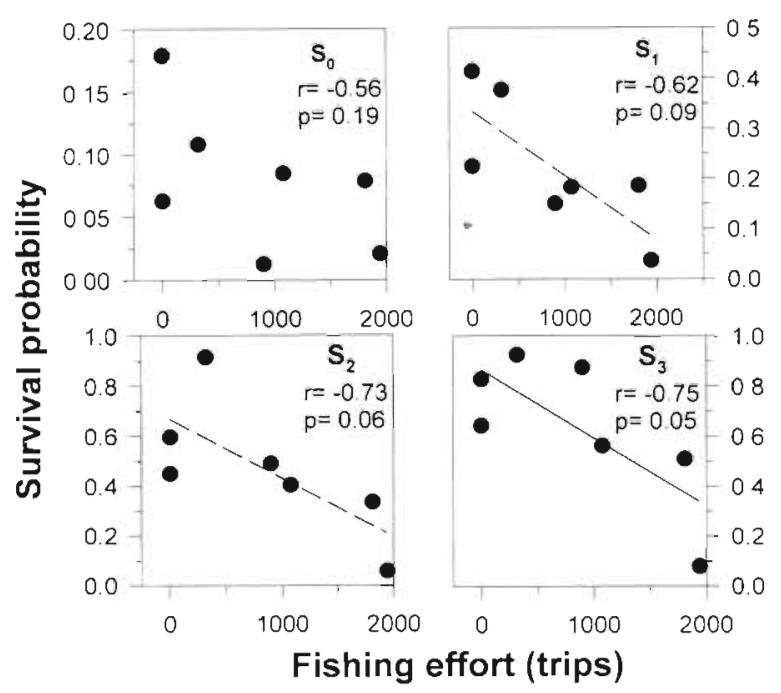

Fig. 2. Mesodesma mactroides. Bivariate correlations between age-specific survival probability and fishing effort. Estimated correlation coefficients and their corresponding statistical significance are presented on the right side of each graph

separately. Vital rates varied widely throughout the 8 yr analyzed, the age-specific fertility showing higher coefficients of variation ( $80 \%$ ) than the corresponding survivals (40 to $60 \%$ ). Survival probabilities of Age classes 1,2 and 3 were inversely correlated $(r=-0.62$ to $-0.75, p<0.10$ ) with fishing effort (number of fishing trips), and $S_{0}$ was also negatively correlated with this variable but not significantly $(r=-0.56, p=0.19$ ) (Fig. 2). The age-specific survival was also strongly negatively correlated with population density, significantly in Age classes 1, 2 and $3(r=-0.81$ to $-0.86, p<$ $0.05)$, but not in Age class $0(r=-0.63, p=0.13)$ (Fig. 3 ).

Age-specific fertility and recruitment were associated with adult density according to a dome-shaped model (Fig. 4). Maximum fertility and recruitment occurred at low to medium adult density, while high adult density resulted in extremely low fertility and recruitment. Predicted fertility and recruitment dropped when adult density was above a certain threshold value, 50 adults $\mathrm{m}^{-2}$ for fertility and 100 adults $\mathrm{m}^{-2}$ for recruitment, and then decreased to almost zero at 220 adults $\mathrm{m}^{-2}$ (Fig. 4). These high densities were observed during the third year of harvest closure (1989) and just after the clam fishery reopened (1990).

\section{Age structure}

The age structure over the 8 yr of study did not differ from the average stable age structure derived from the matrix model (chi-square test, $\chi^{2}=0.381, p>0.95$ ). Age class 0 dominated the population with a relative abun- 


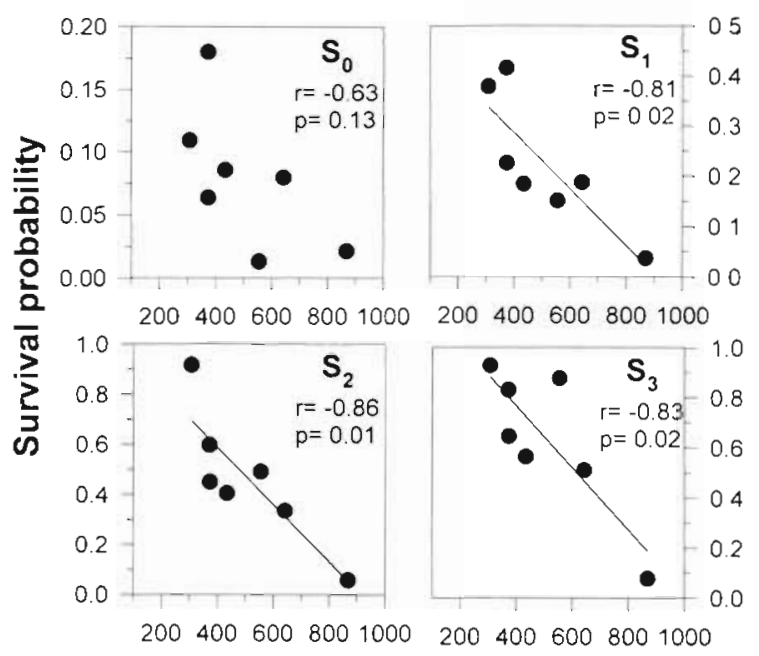

Population density (ind. $\mathrm{m}^{-2}$ )

Fig. 3. Mesodesma mactroides. Bivariate correlations between age-specific survival probability and yellow clam population density. Estimated correlation coefficients and their corresponding statistical significance are presented

dance of $0.87 \pm 0.11$. The proportion of Age class 1 clams was $0.071 \pm 0.037$ of the total population abundance, whereas those of Age classes 2, 3 and 4 were less than 0.03 each. The age-specific relative abundance showed little temporal variability, and was not correlated with fishing effort or recruitment density ( $p>0.30)$. However, the age-specific relative abundance was moderately correlated with adult density $(r=0.58$ to $0.70, p<0.10)$, negatively in the case of the Age class 0 and positively for Age classes 2, 3 and 4 . The relative abundance of adult classes (2,3 and 4) was in general very low during the pre-closed period, but increased at the end of the closed period, especially in 1989 and 1990 (see Table 1).

\section{Elasticity analysis}

The elasticity analysis showed that the survival probability of Age class $0\left(S_{0}\right)$ and fertility of Age class $1\left(F_{1}\right)$ were the most important demographic parameters in determining population growth rates $\lambda_{e}$ (Fig. 5). $\lambda_{e}$ was more sensitive to changes in demographic parameters of younger ages $\left(S_{0}, S_{1}\right.$ and $\left.F_{1}\right)$ (pooled elasticities: $0.81)$ than in older ones $\left(S_{2}, F_{2}\right.$ and $\left.F_{3}\right)$ (pooled elasticities: 0.19). Elasticity was almost equally allocated between age-specific survival probabilities (pooled elasticities: 0.60) and fertilities (pooled elasticities: 0.40 ) (Fig. 5). Temporal variability of the elasticity of $\lambda_{e}$ with regard to the different demographic parameters was significantly correlated with adult density and 1 yr delayed fishing effort (Table 2). The elasticities of $\lambda_{\mathrm{e}}$ to
$S_{0}$ and $F_{1}$ were positively correlated with 1 yr delayed fishing effort, and inversely correlated with adult density, while the elasticities of $\lambda_{\mathrm{e}}$ to $S_{1}, S_{2}, F_{2}$ and $F_{3}$ showed the opposite trend (Table 2).

\section{Population density}

Population density of Mesodesma mactroides varied widely during the period 1983 to 1990, from 150 ind. $\mathrm{m}^{-2}$ in 1986 to 900 ind. $\mathrm{m}^{-2}$ in 1985, mainly tracking

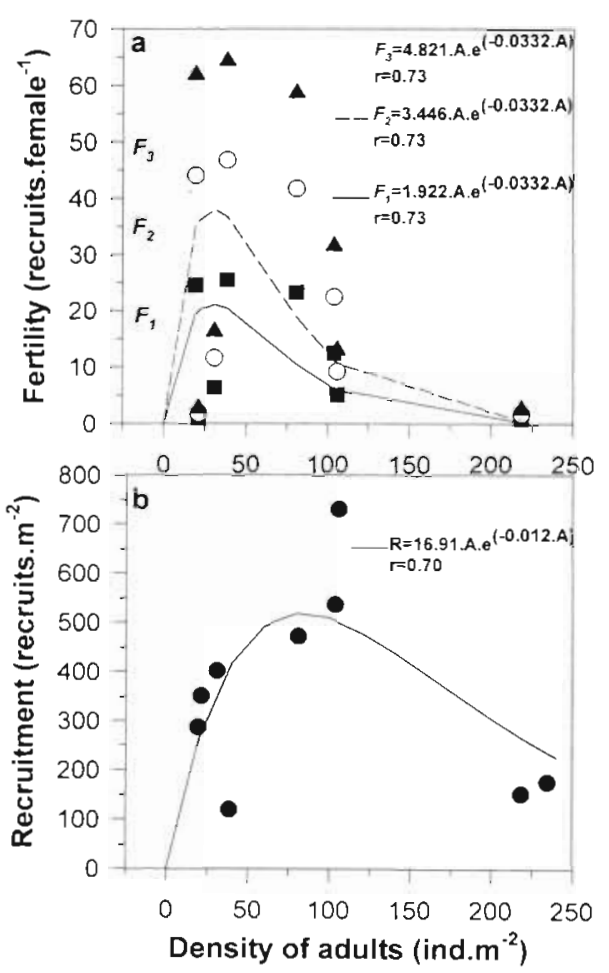

Fig. 4. Mesodesma mactroides. Relationships between adult density and (a) age-specific fertility and (b) recruitment. The nonlinear equations estimated for each age and for recruitment are presented

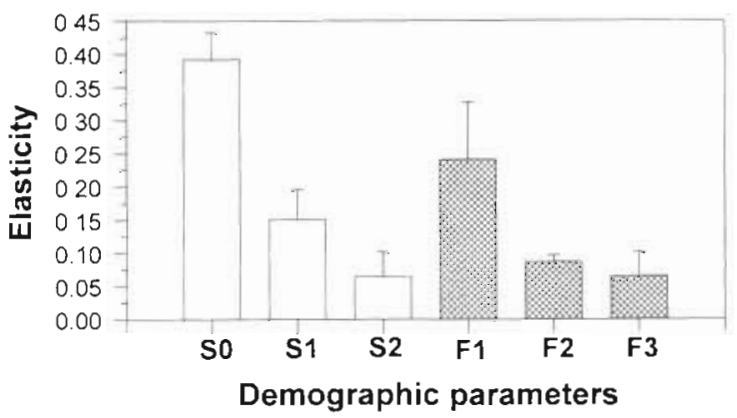

Fig. 5. Mesodesma mactroides. Elasticity (mean \pm SD) of population growth rate $\left(\lambda_{e}\right)$ versus the demographic parameters survival and fertility, separated by age class 
Table 2. Values of Pearson product-moment correlation between the elasticity of $\lambda_{\mathrm{e}}$ to the vital rates $\left(E-S_{\|} E-F_{1}\right)$ and the following variables: fishing effort $(F E), 1$ yr delayed fishing effort (1YFE), and density of recruits $(R D)$ and of adults $(A D)$. Significant correlations (i.e. $p<0.05$ ) in bold type

\begin{tabular}{|lcccccc|}
\hline \multirow{2}{*}{ Variable } & \multicolumn{6}{c|}{ Elasticity of $\lambda_{\mathrm{e}}$ to vital rates } \\
& $E-S_{0}$ & $E-S_{1}$ & $E-S_{2}$ & $E_{-} F_{1}$ & $E_{-} F_{2}$ & $E-F_{3}$ \\
\hline$F E$ & 0.61 & -0.61 & -0.62 & 0.61 & -0.47 & -0.62 \\
$1 Y F E$ & $\mathbf{0 . 9 0}$ & $-\mathbf{0 . 9 0}$ & $-\mathbf{0 . 9 0}$ & $\mathbf{0 . 9 0}$ & $\mathbf{- 0 . 7 6}$ & $\mathbf{- 0 . 9 0}$ \\
$R D$ & 0.33 & $\mathbf{- 0 . 3 0}$ & -0.38 & 0.32 & 0.03 & -0.38 \\
$A D$ & $-\mathbf{0 . 8 1}$ & $\mathbf{0 . 8 1}$ & $\mathbf{0 . 7 9}$ & $\mathbf{- 0 . 8 1}$ & $\mathbf{0 . 7 5}$ & $\mathbf{0 . 7 9}$ \\
\hline
\end{tabular}

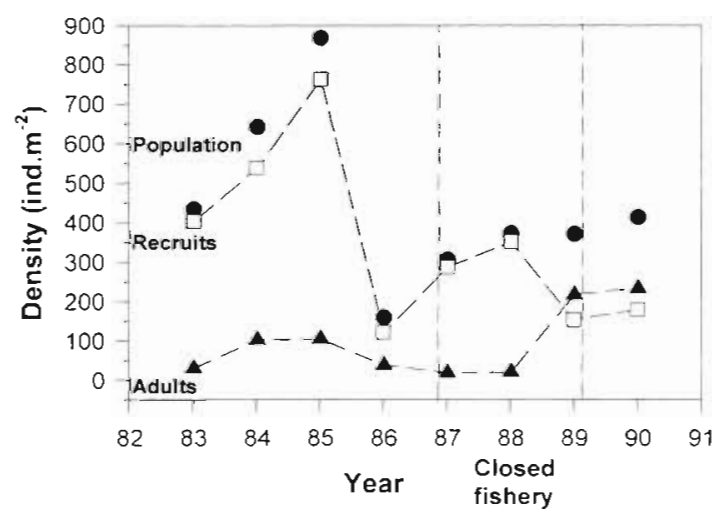

Fig. 6. Mesodesma mactroides. Annual density fluctuations of

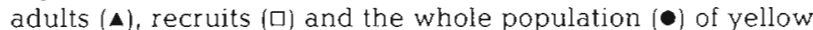
clams in Uruguay, from 1983 to 1990 . The period of closed fishery (April 1987 to November 1989) is indicated

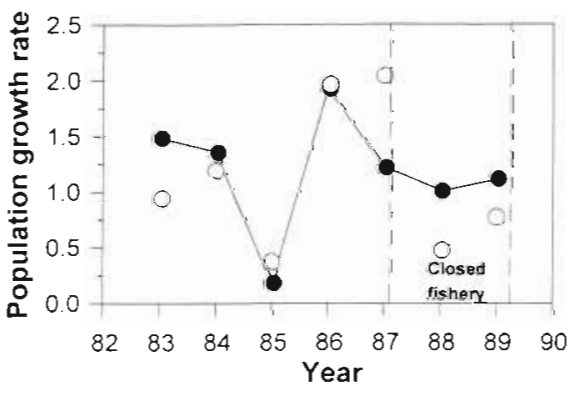

Fig. 7. Mesodesma mactroides. Observed ( $\bullet$ and estumated (O) population growth rates of yellow clams in Uruguay. during the period 1983 to 1990 . The closed fishery period is indicated

recruitment variations $(r=0.93, p=0.003)$. Recruitment peaked in 1985, when adult density was at an intermediate level and the clams were subject to intensive harvesting, and was lowest in 1986. It reached very low values in 1989, during the third year of the closed season, and in the autumn of 1990, only 4 mo after fishery reopening (Fig 6). Contrasting with recruitment variation, adults showed 2 peaks of different intensity: one in 1985 and another 2 yr after the fishery closure (1989-1990), reaching nearly twice the mean level during pre-closure years. Adult density was lowest in 1987, at the beginning of the fishery closure (Fig. 6). Adult density was inversely correlated with the fishing effort exerted the year before. This was especially evident when the information on the fishing effort of 1987 , which corresponds to a transitional period between the end of the exploited phase and the beginning of the experimental closure of the fishery, was omitted from the analysis $(r=-0.93, p=0.007)$.

\section{Population growth rate}

The observed mean population growth rate $\left(\lambda_{0}\right)$ was $1.18 \pm 0.49$ (mean $\pm \mathrm{SD}$ ) and did not differ from the mean value $\left(\lambda_{e}: 1.06 \pm 0.59\right)$ estimated by the matrix model. Annual values of $\lambda_{0}$ and $\lambda_{e}$ were lowest in 1985 , coinciding with the peak of fishing effort and population density, and highest in 1986, under low adult density (Fig. 7, see also Fig. 6)

\section{DISCUSSION}

Our long-term study of the yellow clam Mesodesma mactroides strongly suggested that harvesting and density-dependent factors could substantially modify the demographic structure and dynamics of sandy beach populations. The experimental manipulation of fishing effort showed the implications of humans as top predators in the system, affecting population structure and long-term demographic properties. In this context, 32 mo of fishery closure were a powerful tool in revealing the role that density-dependent factors play by affecting both fine- (e.g. age-specific mortality and fertility) and coarse-scale (e.g. population abundance) population traits.

\section{Demographic consequences of harvesting}

Clam harvesting intensity was inversely correlated with the age-specific survival probabilities of older ages (i.e. 1 to 3, harvested age classes), and seemed to have no significant effects on the young-of-the-year, although a negative correlation was also observed. But, considering that Mesodesma mactroides is commercially exploited with shovels, there is collateral damage (broken shells due to hand-gathering techniques) to the unexploited size classes (i.e. $<50 \mathrm{~mm}$; Defeo 1996a). This harvesting technique may also affect the survival of young clams by disturbing the sediment and altering sediment properties. thus 
restricting the movement of burrowing organisms and increasing natural mortality rates (Defeo 1993, 1996a, Lubchenco et al. 1995 and references therein). These harvesting effects should ideally be estimated through field experiments (see Peterson 1975, 1977, Wynberg \& Branch 1994, Hall \& Harding 1997 for sandflat ecosystems).

A fine-scale spatial analysis of the impact of fishing on the young-of-the-year revealed the highest mortality rates in heavily harvested grounds (Defeo 1996a, 1998). This suggests that harvesting could negatively affect the survival probability of the young-of-the-year at smaller spatial scales (i.e. a fishing ground, $5 \mathrm{~km}$; Defeo 1998) than that considered in this study (i.e. the whole beach, $22 \mathrm{~km}$ ). The reasons why harvesting influence is scale-dependent are unknown, but this means that at larger scales the survival of Age class 0 individuals might be mainly controlled by other factors than harvesting, probably physical ones. One of these unknown factors affecting recruitment survivorship could be salinity. In this sense, Defeo et al. (1986) and Defeo $(1993,1996 b)$ showed that the spatial distribution of Mesodesma mactroides recruits is strongly affected by the salinity gradient generated by the outlets of the Andreoni channel and Chuy stream (Defeo 1993, 1996b).

Harvesting also seemed to affect the density of adults, a coarse-scale population characteristic. The correlation between adult density and 1 yr delayed fishing effort suggests that harvesting indirectly controlled recruitment, because it reduces (with 1 yr of delay) the adult stock, which in turn affects fertility and recruitment intensity (see Fig. 4). This indicates that harvesting intensity may play an important role in moderating the intensity of future density-dependent processes in Mesodesma mactroides at the level of fertility and recruitment (see also Defeo 1996a, 1998).

The youngest age classes (i.e. $S_{0}$ and $F_{1}$ ) had the largest elasticities, which is a typical feature of shortlived organisms (see Stearns 1992). Although the elasticity of $\lambda_{\mathrm{e}}$ to $S_{0}$ and $F_{1}$ did not show important temporal variation, it increased with increasing 1 yr delayed fishing effort. This suggests that the importance of these significant demographic parameters to population growth rate increases under conditions of high fishing activity.

\section{Demographic consequences of density dependence}

Evidence of density-dependent mortality was found in Mesodesma mactroides, especially in older ages, suggesting that intraspecific competition could importantly affect the dynamics of this sandy beach population. This is in agreement with the results obtained by
Defeo (1993, 1998), who observed density-dependent mortality rates for the young-of-the-year and a depression of growth rates of recruits at high adult densities.

Evidence of density dependence was also observed in fertility and recruitment. Both the age-specific fertility and recruitment of Mesodesma mactroides were associated with adult density by a dome-shaped curve. The density-dependent or overcompensatory phase, i.e. the decreasing right-hand of the curve, could be explained by 2 non-excluding hypotheses: (1) Gamete production could decline as crowding increases. This density-dependent small-scale process would occur at a 'pre-dispersal' phase and involves reduced fecundity and recruitment due to either competition for food or prime habitat, depending on concentration ('density experienced by individuals in their immediate neighborhoods': Orensanz, \& Jamieson 1998). (2) In a 'postdispersal' phase, adult individuals could filter passively settling larvae, therefore inhibiting settlement and subsequent recruitment (Defeo 1993, 1996b). This constitutes a major process explaining settlement inhibition by established suspension feeders in soft-bottom habitats (see also Defeo 1998 and references therein).

Density effects were also suggested by the elasticity analysis. The elasticity of $\lambda_{e}$ to $S_{0}$ and $F_{1}$ (the most important parameters) increased with decreasing density, suggesting that these parameters are particularly important in explaining variations in population growth rate under low population density.

In summary, important demographic processes of Mesodesma Mactroides were significantly affected by population density, suggesting density-dependent regulation. This result is particularly meaningful for sandy beach population ecology, where the dominant paradigm is based on the concept of population regulation by physical factors (i.e. density independence) (McLachlan 1983, 1988, 1990, but see Defeo 1993, 1996a, Defeo et al. 1997). Although it is known that factors such as wave exposure (e.g. Eleftheriou \& Nicholson 1975), intertidal slope (e.g. McLachlan et al. 1981) and grain size (Jaramillo \& McLachlan 1993) have an important role, our results strongly suggest that physical factors do not exclusively regulate sandy beach populations. It seems, as is predicted by population theory (see Royama 1992), that sandy beach populations, as well as those of high-energy sand flats (see Peterson 1977, 1982, Peterson \& Black 1988), are controlled by the interaction between density-independent and density-dependent factors.

\section{Management implications}

Traditional studies of intertidal organisms have often ignored or underestimated the role of man as an inter- 
acting species, specifically as a top predator in the system (but see e.g. Peterson 1975, Castilla \& Durán 1985. Durán \& Castilla 1989, Bustamante \& Castilla 1990, de Alava 1993). The present study, which assessed the long-term effects of human exploitation on the demography of Mesodesma mactroides, showed some positive effects of harvesting, in the sense that it prevents the site from becoming saturated with individuals. Thus, the probability of occurrence of density-dependent effects in recruitment success and mortality might decrease.

The exclusion of humans for 32 mo resulted in a strong recovery of the population and a subsequent heavy failure in recruitment 2 yr after the closure of the fishery. This suggests that a relatively long closed season may have negative consequences for the resource and the fishery. Adequate exploitation levels could be useful to (1) prevent monopoly of space by adults; (2) increase settlement/recruitment rates of targeted and non-harvested sympatric filter feeders (e.g. Donax hanleyanus, see de Alava 1993, Defeo \& de Alava 1995); and (3) maximise the net benefits derived from the fishery to the coastal fishing community.

Highest fertility and recruitment occurred at intermediate levels of adult density and fishing effort, whereas these processes were strongly inhibited by the high adult densities reached 2 yr after the experimental closure of the fishery. This finding has immediate repercussions from a management point of view (see also Defeo 1993, 1998): (1) It allows the definition of a threshold range of parent stock density (around 100 ind. $\mathrm{m}^{-2}$ ) and fishing mortality levels capable of supporting a sustainable yield over time, by increasing the probability of generating a desired recruitment level. (2) Even though the exclusion of humans resulted in a rapid recovery of the population, 3 yr of fishery closure led to a dramatic reduction in recruitment as a result of strong overcompensatory processes. An optimal harvesting strategy should minimise density dependent effects, as well as those derived from high intensity levels of fishing. Thus, if required, shorter periods (i.e. 1 or 2 yr) of fishery closure are recommended.

The elasticity analysis provided useful information from the management and conservation point of view, by indicating which are the most important demographic parameters to manage. Our results indicate that the survival probability of Age class 0 and the fertility of Age class 1 are critical in the determination of the population growth of Mesodesma mactroides, particularly at low adult density. The lack of selectivity in the harvesting process emphasizes the need to increase the survival of Age class 0 individuals by setting harvesting strategies directed to protect them from incidental damage and/or natural mortality agents produced by disruption of the sediment structure. A precautionary approach should be to restrict the use of industrial-scale harvesting technologies (e.g. tractors, see Defeo et al. 1993) and continue using hand-gathering harvesting techniques.

The design of a reproductive refugium together with a spatial rotation of fishing grounds could be useful to increase the survival of Age class 0 and fertility of Age class 1 , because the yellow clam constitutes a spatially structured population (sensu Orensanz \& Jamieson 1998) subject to heterogeneous harvesting intensity. In this context, fishing grounds with lower productivity could be used as exploitation units during the spawning and recruitment seasons (see Defeo et al, 1993), thus minimising incidental mortality rates. The most productive grounds, which constitute areas of high adult density and recurrent and successful recruitment (Defeo 1998), could then be used prior to spawning and recruitment. This strategy should generate space and a certain level of adult density that enables recruitment success at desirable levels.

Acknowledgements. We thank Pablo Marquet, Mauricio Lima and Fabián Jaksic for critically reading early versions of the manuscript. We also thank 4 anonymous referees for their contribution. Financial support was partially provided by CONICYT (Uruguay) (Project No. 1018). A.B. is a doctoral student of the Pontificia Universidad Católica de Chile.

\section{LITERATURE CITED}

Borzone CA, Souza JRB, Soares AG (1996) Morphodynamics and tropical macrofaunal structure. Rev Chil Hist Nat 69: 565-577

Brazeiro A (1993) Evaluación del impacto ecológico provocado por el canal Andreoni sobre el ecosistema arenoso comprendido entre La Coronilla y Barra del Chuy (Rocha, Uruguay). Aspectos abióticos. Informe final. CONICYT (Uruguay), Montevideo

Bustamante R, Castilla JC (1990) Impact of human exploitation on populations of the intertidal southern bull-kelp Durvillae antarctica (Phaeophyta, Durvilleales) in central Chile. Biol Conserv 52:205-220

Castilla JC (1993) Humans: capstone strong actors in the past and present coastal ecological play. In: McDonnell MJ, Pickett STA (eds) Humans as components of ecosystems: the ecology of subtle human effects and populated areas. Springer-Verlag, New York, p 158-162

Castilla JC, Duran R (1985) Human exclusion from the rocky intertidal zone of central Chile: the effects on Concholepas concholepas (Gastropoda). Oikos 45:391-399

Caswell H (1989) Matrix population models. Sinauer Associates, Sunderland, $\mathrm{MA}$

de Alava A (1993) Interdependencias ecológicas entre dos bivalvos simpátricos en una playa arenosa de la costa atlántica uruguaya. MSc thesis, Centro de Investigación y de Estudios Avanzados del Instituto Politécnico Nacional (México)

Defeo O (1985) Aspectos biocenológicos y de dinámica de población de 'almeja amarilla', Mesodesma mactroides 
(Deshayes, 1854) en la zona de la Barra del Chuy Depto de Rocha, Uruguay. I. Biocenología. Contrib Dep Oceanogr Montevideo 2:50-75

Defeo O (1989) Development and management of artisanal fishery for yellow clam Mesodesma mactroides in Uruguay. Fishbyte 7:21-25

Defeo O (1993) The effect of spatial scales in population dynamics and modelling of sedentary fisheries: the yellow clam Mesodesma mactroides of an uruguayan exposed sandy beach. PhD dissertation thesis, Centro de Investigación y de Estudios Avanzados del Instituto Politécnico Nacional (México)

Defeo O (1996a) Experimental management of an exploited sandy beach bivalve population. Rev Chil Hist Nat 69: $605-614$

Defeo O (1996b) Recruitment variability in sandy beach macroinfauna: much to learn yet. Rev Chil Hist Nat 69 : $615-630$

Defeo O (1998) Testing hypotheses on recruitment, growth and mortality in exploited bivalves: an experimental perspective. In: Jamieson G, Campbell A (eds) North Pacific Symposium on Invertebrate Stock Assessment and Management. Can Spec Publ Fish Aquat Sci 125 : $257-264$

Defeo O, de Alava A (1995) Effect of human activities on longterm trends in sandy beach populations: the wedge clam Donax hanleyanus in Uruguay. Mar Ecol Prog Ser 123: $73-82$

Defeo O, Layerle C, Masello A (1986) Spatial and temporal structure of the yellow clam Mesodesma mactroides (Deshayes, 1854) in Uruguay. Medio Ambiente (Chile) 8 $48-57$

Defeo O, Jaramillo E, Lyonnet A (1992a) Community structure and intertidal zonation of the macroinfauna in the Atlantic coast of Uruguay. J Coast Res 8:830-839

Defeo O, Ortiz E, Castilla JC (1992b) Growth, mortality and recruitment of the yellow clam Mesodesma mactroides on Uruguayan beaches. Mar Biol 114:429437

Defeo O, de Alava A, Valdivieso V, Castilla JC (1993) Historical landings and management options for the genus Mesodesma in coasts of South America. Biol Pesq (Chile) 22:41-54

Defeo O, Brazeiro A, de Alava A, Riestra G (1997) Is sandy beach macroinfauna only physically controlled? Role of substrate and competition in isopods. Estuar Coast Shelf Sci 45:453-462

Durán LR, Castilla JC (1989) Variation and persistence of the middle rocky intertidal community of central Chile, with and without human harvesting. Mar Biol 103:555-562

Eberhardt LL (1988) Using age structure data from changing populations. J Appl Ecol 25:373-378

Efford IE (1970) Recruitment to sedentary marine populations as exemplified by the sand crab, Emerita analoga (Decapoda, Hippidae). Crustaceana 18:293-308

Eleftheriou A, Nicholson MD (1975) The effects of exposure on beach fauna. Cah Biol Mar 16:695-710

Hall SJ, Harding MJC (1997) Physical disturbance and marine benthic communities: the effects of mechanical harvesting of cockles on non-target benthic infauna. J Appl Ecol 34:497-517

Jaramillo E, McLachlan A (1993) Community and population responses of the macroinfauna to physical factors over a range of exposed sandy beaches in south-central Chile Estuar Coast Shelf Sci 37:615-624
Lubchenco J, Allison GW, Navarrete SA, Menge BA, Castilla JC, Defeo O, Folke C, Kussakin O, Norton T, Wood AM (1995) Section 6.1.9. Coastal systems. In: Heywood YH (ed) United Nations Environment Programme. Global Biodiversity Assessment. Section 6: Biodiversity and ecosystem functioning: ecosystem analyses. Cambridge University Press, Cambridge, p 370-381

Masello A, Defeo O (1986) Determinación de la longitud de primera madurez sexual en Mesodesma mactroides (Deshayes, 1854). Comun Soc Malacol Uruguay 6:387-392

McLachlan A. (1983) Sandy beach ecology - a review. In: Mclachlan A, Erasmus T (eds) Sandy beaches as ecosystems. W Junk, The Hague, p 321-380

McLachlan A (1988) Behavioural adaptations of sandy beach organisms: an ecological perspective. In: Chelazzi G, Vannini $M$ (eds) Behavioural adaptations to intertidal life. Plenum Publishing Corporation, New York, p 449-475

McLachlan A (1990) Dissipative beaches and macrofauna communities on exposed intertidal sands. J Coast Res 6: $57-71$

McLachlan A, Wooldridge T, Dye AH (1981) Sandy beach macrofauna communities and their control by the physical environment: a geographical comparison. S Afr J Zool 16: $219-231$

McLachlan A, Jaramillo E, Don TE, Wessels F (1993) Sandy beach macrofauna communities and their control by the physical environment: a geographical comparison. J Coast Res (Spec Issue) 15:27-38

McLachlan A, de Ruyck A, Hacking N (1996) Community structure on sandy beaches: patterns of richness and zonation in relation to tide range and latitude. Rev Chil Hist Nat 69:451-467

Oliva D, Castilla JC (1986) The effect of human exclusion on the population structure of keyhole limpets Fissurella crassa and Fissurella limbata on the coast of central Chile. PSZN I: Mar Ecol 7:201-217

Orensanz J, Jamieson G (1998) The assessment and management of spatially structured stocks. In: Jamieson G, Campbell A (eds) North Pacific Symposium on Invertebrate Stock Assessment and Management. Can Spec Pub Fish Aquat Sci 125:441-459

Peterson $\mathrm{CH}$ (1975) Stability of species and community for the benthos of two lagoons. Ecology 56:958-965

Peterson $\mathrm{CH}$ (1977) Competitive organization of the soft-bottom macrobenthic communities of southern California lagoons. Mar Biol 43:343-359

Peterson $\mathrm{CH}$ (1982) The importance of predation and intraand interspecific competition in the population biology of two infaunal suspension-feeding bivalves, Protothaca staminea and Chione undatella. Ecol Monogr 52:437-475

Peterson CH, Black R (1988) Density-dependent mortality caused by physical stress interacting with biotic history. Am Nat 131:257-270

Royama T (1992) Analytical population dynamics. Chapman and Hall, London

Short AD, Wright LD (1983) Physical variability of sandy beaches. In: McLachlan A, Erasmus $T$ (eds) Sandy beaches as ecosystems. W Jurk, The Hague, p 133-144

Stearns SC (1992) The evolution of life histories. Oxford University Press, New York

Wynberg RP, Branch GM (1994) Disturbance associated with bait-collection for sandprawns (Callianassa kraussi) and mudprawns (Upogebia africana): long-term effects on the biota of intertidal sandflats. J Mar Res 52:523-558 